九州大学学術情報リポジトリ

Kyushu University Institutional Repository

Effects of Irrigation and Nitrogen Fertilization on Photosynthesis, Leaf Area Index and Dry Matter Production of Wheat on a Clay Terrace Soil of Bangladesh

Rahman M., Ataur

MS student, Department of Soil Science, Bangabandhu Sheikh Mujibur Rahman Agricultura University

Karim, Sirajul A. J. M.

Hoque M., M.

Department of Soil Science, Bangabandhu Sheikh Mujibur Rahman Agricultural University

Egashira, Kazuhiko

Laboratory of Soil Science, Division of Soil Science and Plant Production, Department of Plant Resources, Faculty of Agriculture, Kyushu University

https://doi.org/10.5109/24378

出版情報: 九州大学大学院農学研究院紀要. 45 (1)，pp. 289-300，2000-11. Kyushu University バージョン：

権利関係 : 


\title{
Effects of Irrigation and Nitrogen Fertilization on Photosynthesis, Leaf Area Index and Dry Matter Production of Wheat on a Clay Terrace Soil of Bangladesh
}

\author{
M. Ataur Rahman*, A. J. M. Sirajul Karim**, M. M. Hoque** \\ and Kazuhiko Egashira***
}

\author{
Laboratory of Soil Science, Division of Soil Science and Plant Production, \\ Department of Plant Resources, Faculty of Agriculture, \\ Kyushu University, Fukuoka 812-8581, Japan \\ (Received June 1, 2000 and accepted August 18, 2000)
}

\begin{abstract}
A field research was conducted at the university farm of Bangabandhu Sheikh Mujibur Rahman Agricultural University, Bangladesh, during November 1997 to March 1998 in order to study the effects of irrigation and nitrogen fertilization on the leaf photosynthesis, leaf area index and dry matter production of wheat. The experiment was executed in the split-plot design comprising the combination of the five levels of irrigation arranged as a main plot and the four rates of $\mathrm{N}$ application distributed to a sub plot. The five irrigation treatments were: $\mathrm{I}_{0}-$ no irrigation after the establishment of seedlings; $I_{1}$-one irrigation at 23 days after sowing (DAS) of wheat seeds; $\mathrm{I}_{2}$-two irrigations: one at 23 DAS and the other at 60 DAS; $\mathrm{I}_{3}$-two irrigations: one at $23 \mathrm{DAS}$ and the other at $80 \mathrm{DAS} ; \mathrm{I}_{4}-$ three irrigations: at 23,60 and $80 \mathrm{DAS}$. The four rates of $\mathrm{N}$ application were: $\mathrm{N}_{6}-$ no application of $\mathrm{N}$ fertilizer; $\mathrm{N}_{i}, \mathrm{~N}_{2}$ and $\mathrm{N}_{3}-$ application of $\mathrm{N}$ at the rates of 80,120 and $160 \mathrm{~kg} \mathrm{ha}^{-1}$, respectively. Both irrigation and $\mathrm{N}$ application have created a significant impact on leaf photosynthesis (LPn), leaf area index (LAI), crop growth rate (CGR) and biomass production of wheat. Irrigation scheduling which included irrigation at the grain filling stage (80DAS) coupled with $\mathrm{N}$ application up to $120 \mathrm{~kg} \mathrm{ha}^{-1}$ significantly increased LPn, LAI, CGR and biomass production. With respect to the growth stage, LPn and CGR were highest, at the anthesis stage (70-75 DAS) and LAI was maximum at the booting stage (60 DAS). Increased dry matter accumulation at maturation was mainly due to the increased weight of grains.
\end{abstract}

\section{INTRODUCTION}

Irrigation water and fertilizer $\mathrm{N}$ are the most important inputs for optimum growth and development of wheat in Bangladesh where the entire growing period of wheat is dry and most of the soils under wheat is deficient in $\mathrm{N}$. Adequate $\mathrm{N}$ application with enough available moisture at the critical growth stages is important to optimize growth and physiological processes leading to the increased dry matter production. Grain yield is a function of dry matter accurnulation and harvest index.

* MS student, Department of Soil Science, Bangabandhu Sheikh Mujibur Rahman Agricultural University, Salna, Gazipur 1703, Bangladesh; currently serving at Wheat Research Center, Noshipur, Dinajpur, Bangladesh

** Department of Soil Science, Bangabandhu Sheikh Mujibur Rahman Agricultural University, Salna, Gazipur 1703, Bangladesh

*** Corresponding author (E-mail: kegashi@agr.kyushu-u.ac.jp) 
Water has a vital role in nutrient transport from soil to plant and it is a raw material of photosynthesis (Pn). The amount of water used in Pn is negligible compared to the consumptive use of water by plant, but the Pn process is very sensitive to water stress. Water deficit causes closing of stomata resulting in the poor Pn activity. Benbi (1994) reported that the rate and extent of leaf area development were dependent on the amount and pattern of water supply. Transpiration rate, stomatal width and $\mathrm{CO}_{2}$ conductivity in the mesophyll decreased under intermediate to severe water deficit condition that caused the reduction of Pn in leaves (Liu and Chen, 1990). Under water deficit condition plant maintains turgor at the expense of cell growth (Hsiao, 1973) and the growth is seriously hampered.

Wheat requires a large amount of $\mathrm{N}$ for rapid growth, as it is a component of protein, amino acid, amino sugar and nucleic acid. Parameswaran et al. (1984) reported that the growth rate of wheat increased with the increasing $\mathrm{N}$ application rate up to $130 \mathrm{~kg} \mathrm{ha}^{-1}$ and the optimum amount of $\mathrm{N}$ gave the higher leaf area and the longer post anthesis green area duration leading to the increased total $P n$ and grain yield.

Neither irrigation nor $\mathrm{N}$ alone but the balanced application of these two inputs can optimize wheat growth. Singh and Dubey (1989) suggested that the yield increase of wheat under the adequate irrigation and higher doses of $\mathrm{N}$ was associated with more production of photosynthates and their translocation to the sink. Systematic study on the effects of irrigation and $\mathrm{N}$ fertilization on the growth of wheat is limited in Bangladesh. The present study aims at examining the effects of the irrigation and $\mathrm{N}$ fertilization on the leaf photosynthesis, leaf area index and dry matter production of wheat cultivated on a clay terrace soil.

\section{MATERIALS AND METHODS}

\section{Location and soil}

The experiment was executed at the research farm of Bangabandhu Sheikh Mujibur Rahman Agricultural University (BSMRAU), Gazipur, Bangladesh during November 1997 to March 1998. It is located at the center of Madhupur tract $\left(24^{\circ} 05^{\prime} \mathrm{N}\right.$ and $90^{\circ} 16^{\prime} \mathrm{E}$ ) at an elevation of $8.4 \mathrm{~m}$ above sea level and is $40 \mathrm{~km}$ north of Dhaka, the capital. The soil of the experimental field belongs to Salna series and has been classified as Shallow Red-Brown Terrace Soil in Bangladesh soil classification system which is nearly equivalent to Ochrepts in Soil Taxonomy.

\section{Climate}

Climate in Madhupur tract is dominated by the subtropical monsoon with most rainfall during the months of the premonsoon and monsoon seasons (April to September) and scanty rainfall during the rabi season (October to March, the wheat growing season). The little rainfall in the rabi season is uncertain and unevenly distributed (Karim and Egashira, 1995). The mean air temperature in the rabi season varies between 12 and $31^{\circ} \mathrm{C}$ in Bangladesh which is favourable for a wide variety of crops.

\section{Soil analyses}

The texture was determined by the hydrometer method. Bulk density at different 
depths was determined by the core sampling method (outlined by Karim et al., 1988). The soil moisture at field capacity (FC) was determined by ponding a small portion of the field by water for several hr and then allowing water to recede down through the soil profile. Soil moisture was monitored gravimetrically at $24-\mathrm{hr}$ interval for 7 days. When soil moisture of the two subsequent readings became nearly the same it was considered to be the moisture at FC.

Soil $\mathrm{pH}$ was measured by $\mathrm{pH}$ meter (Model: No. M-8L, Horiba, Japan) fitted with a glass electrode using a soil:water ratio of 1:2.5. Organic $\mathrm{C}$ and total $\mathrm{N}$ of the soil were determined by the Tyurin and the Kjeldahl methods, respectively.

\section{Test crop}

The high-yielding variety of wheat "Protiva" was used as the test crop. This variety was released by Wheat Research Center of Bangladesh Agricultural Research Institute in 1995. Seeds were collected from Wheat Research Center, Dinajpur and the germination percentage of the seed was reported to be about $90 \%$.

\section{Experimental design}

The experiment was laid out in the split-plot design with three replications. Two factors of irrigation and $\mathrm{N}$ application were involved in the experiment. Five irrigation treatments were arranged to the main plot and four $\mathrm{N}$ treatments were distributed to the sub-plot. The treatments were assigned to the experimental units randomly.

Factor A-Irrigation: The five levels of irrigation were as follows:

$\mathrm{I}_{0}$ : No irrigation after the establishment of seedlings;

$\mathrm{I}_{1}$ : One irrigation at the crown root initiation stage (CRI) (23 days after sowing (DAS));

$\mathrm{I}_{2}$ : Two irrigations-one at CRI and the other at the booting stage (60 DAS);

$\mathrm{I}_{3}$ : Two irrigations-one at CRI and the other at the grain filling stage (80DAS);

$\mathrm{I}_{4}$ : Three irrigations-the first at CRI, the second at the booting stage, and the third at the grain filling stage.

Measured amounts of irrigation water were applied. Irrigation was given to bring the soil moisture to FC up to the rooting depth.

Factor B-Nitrogen: The four rates of $\mathrm{N}$ application were as follows:

$\mathrm{N}_{0}$ : No application of $\mathrm{N}$;

$\mathrm{N}_{1}, \mathrm{~N}_{2}$ and $\mathrm{N}_{3}$ : Application of $\mathrm{N}$ at the rates of 80,120 and $160 \mathrm{~kg} \mathrm{ha}^{-1}$, respectively.

Urea was used as the source of $\mathrm{N}$.

\section{Fertilizer application, sowing of seeds, and cultural operations}

Triple superphosphate (TSP), muriate of potash (MP) and gypsum were applied to supply $\mathrm{P}_{2} \mathrm{O}_{5}, \mathrm{~K}_{2} \mathrm{O}$ and $\mathrm{S}$ at the rates of 60,40 and $20 \mathrm{~kg} \mathrm{ha}^{-1}$, respectively. Total amounts of them and two-thirds of urea were applied plot-wise during final land preparation on the sowing day. The rest amount of urea was top-dressed at 23DAS. After sowing of seeds a common irrigation was given by sprinkler irrigation system to ensure uniform germination of seeds. The soil was loosened only once just before implementation of the first irrigation treatment at CRI. Weeding and thinning of seedlings were done simultaneously 
at that time.

\section{Growth analysis of shoot}

Wheat plant was sampled periodically with a length of $0.5-\mathrm{m}$ plant-row per plot by harvesting at the base. The sampling was done at 20,40,60, 75, 90 and 104DAS. The above-ground plant-parts were segmented into different components of leaf, culm, spike and grain. Leaf area was measured by an automatic leaf area meter (Model: AAM-8, Hayashi Denko, Japan) immediately after sampling. The plant components were then dried in an oven at $70^{\circ} \mathrm{C}$ for $72 \mathrm{hr}$ and weighed.

Leaf area index. Leaf area index (LAI) at different growth stages was calculated by using the following equation:

$\mathrm{LAI}=$ (total surface area of leaves)/(ground area of leaf sampling).

Crop growth rate. Crop growth rate (CGR) was calculated as follows: $\mathrm{CGR}=\left\{\left(\mathrm{W}_{2}-\mathrm{W}_{1}\right) \div\left(\mathrm{T}_{2}-\mathrm{T}_{1}\right)\right\} / \mathrm{GA}$,

where $W_{1}=$ dry weight at time $T_{1}(g)$;

$\mathrm{W}_{2}=$ dry weight at time $\mathrm{T}_{2}(\mathrm{~g})$;

$\mathrm{GA}=$ ground area $\left(\mathrm{m}^{2}\right)$.

Leaf photosynthesis. Leaf photosynthesis (LPn) was measured on the same position of young fully expanded leaves at the vegetative stage and of young flag leaves at the reproductive and maturity stages at the fixed time under full sunshine. The measurement was done using a portable photosynthesis system (Model: Li-COR-LI-6200, Japan) assembled with an infrared gas analyzer (Model: Li-COR-LI-6250, Japan) and data logger, according to the procedure described by Al-Khatib and Paulsen (1990).

\section{Satistical analysis}

The data was statistically analysed through partitioning the total variance with the help of computer "MSTAT" program. The difference between the treatments were compared by LSD (least significant difference) test.

\section{RESULTS AND DISCUSSION}

\section{Soil properties}

Soil samples were collected before initiation of the experiment to examine some basic properties of the experimental soil (Table 1). The soil was silty clay loam in texture at $0-10$ and $10-20 \mathrm{~cm}$ depths and silty clay at $20-30 \mathrm{~cm}$ depth. The soil was compact at the subsurface layers having high bulk densities of 1.66 to $1.78 \mathrm{~g} \mathrm{~cm}^{-3}$, indicating the poor

Table 1. Some basic properties of the experimental soil.

\begin{tabular}{cccccc}
\hline $\begin{array}{c}\text { Soil depth } \\
(\mathrm{cm})\end{array}$ & $\begin{array}{c}\text { Textura1 } \\
\text { class }\end{array}$ & $\begin{array}{c}\text { Bulk density } \\
\left(\mathrm{g} \mathrm{cm}^{3}\right)\end{array}$ & $\begin{array}{c}\text { Field capacity } \\
\text { (\% by wt) }\end{array}$ & $\begin{array}{c}\text { Total N } \\
\left(\mathrm{g} \mathrm{kg}^{-1}\right)\end{array}$ & $\begin{array}{c}\text { Organic C } \\
\left(\mathrm{g} \mathrm{kg}^{-1}\right)\end{array}$ \\
\hline $0-10$ & SiCL & 1.44 & 28.9 & 0.7 & 6.5 \\
$10-20$ & SiCL & 1.66 & 29.1 & 0.4 & 4.8 \\
$20-30$ & SiC & 1.78 & 29.1 & 0.3 & 4.1 \\
\hline
\end{tabular}

Abbreviations: SiCL, silty clay loam; SiC, silty clay. 
drainage condition. Field capacity was around $29 \%$ by weight throughout the profile. The total $\mathrm{N}$ content varied between $0.7 \mathrm{~g} \mathrm{~kg}^{-1}$ at the surface layer and $0.4-0.3 \mathrm{~g} \mathrm{~kg}^{-1}$ at the subsurface layers and the organic $\mathrm{C}$ content varied between 6.5 and $4.1 \mathrm{~g} \mathrm{~kg}^{-1}$, implying the poor soil fertility.

\section{Climatic conditions}

The distribution of mean weekly air temperature, relative humidity and rainfall during the crop-growing period is represented in Table 2 . The air temperature was a little lower in the first half of January, having the mean weekly air temperature of $15.8-15.6^{\circ} \mathrm{C}$ under continuously cloudy sky for most of the hours of the day. The total rainfall during the crop-growing period was $52.7 \mathrm{~mm}$.

Table 2. Mean weekly weather data during the crop-growing period at the experiment site.

\begin{tabular}{|c|c|c|c|c|c|c|}
\hline \multirow{2}{*}{ Week } & \multirow{2}{*}{ Date } & \multicolumn{3}{|c|}{ Mean air temperature $\left({ }^{\circ} \mathrm{C}\right)$} & \multirow{2}{*}{$\begin{array}{c}\text { Relative } \\
\text { humidity (\%) }\end{array}$} & \multirow{2}{*}{$\begin{array}{l}\text { Rainfal } \\
\text { (mm) }\end{array}$} \\
\hline & & Maximum & Minimum & Mean & & \\
\hline 1 & Nov. $20-26$ & 29.3 & 18.8 & 24.1 & 83.1 & - \\
\hline 2 & Nov. 27-Dec. 03 & 27.8 & 18.3 & 23.1 & 82.3 & - \\
\hline 3 & Dec. $04-10$ & 25.8 & 16.1 & 21.0 & 83.1 & 21.7 \\
\hline 4 & Dec. $11-17$ & 23.3 & 14.7 & 19.0 & 89.6 & - \\
\hline 5 & Dec. $18-24$ & 22.0 & 11.7 & 16.9 & 88.7 & - \\
\hline 6 & Dec. $25-31$ & 24.9 & 12.3 & 18.0 & 83.3 & - \\
\hline \multicolumn{2}{|c|}{ Mean of December } & $\mathbf{2 4 . 8}$ & 14.6 & 19.7 & 85.4 & - \\
\hline 7 & Jan. 01-07 & 20.0 & 11.6 & 15.8 & 88.0 & - \\
\hline 8 & Jan. 08-14 & 20.1 & 11.0 & 15.6 & 88.3 & - \\
\hline 9 & Jan. 15-21 & 23.2 & 13.4 & 18.3 & 81.0 & 30.2 \\
\hline 10 & Jan. $22-28$ & 23.7 & 13.1 & 18.4 & 82.0 & - \\
\hline \multicolumn{2}{|c|}{ Mean of January } & 21.8 & 12.3 & $\mathbf{1 7 . 0}$ & 84.8 & - \\
\hline 11 & Jan. 29-Feb. 04 & 26.0 & 14.8 & 20.4 & 75.3 & - \\
\hline 12 & Feb. 05-11 & 26.0 & 12.3 & 19.1 & 76.1 & - \\
\hline 13 & Feb. $12-18$ & 28.1 & 16.3 & 22.2 & 78.6 & - \\
\hline 14 & Feb. $19-25$ & 28.6 & 18.5 & 23.6 & 73.0 & 0.8 \\
\hline \multicolumn{2}{|c|}{ Mean of February } & 27.2 & 15.5 & 21.3 & 75.8 & - \\
\hline 15 & Feb. 26-Mar. 03 & 28.6 & 16.3 & 22.5 & 69.4 & - \\
\hline 16 & Mar. 04-10 & 29.0 & 16.5 & 22.7 & 67.3 & - \\
\hline
\end{tabular}

\section{Leaf photosynthesis}

Growth, development and biomass production of wheat plant depend largely on photosynthates produced by green leaves. The effect of irrigation on LPn was studied at the dough stage (90DAS), since the execution of the irrigation treatment was completed at the grain filling stage ( $80 \mathrm{DAS}$ ) for all the treatments. Leaf photosynthesis was significantly affected by the irrigation treatment (Table 3 ). The plants in the treatments receiving no irrigation after booting $\left(\mathrm{I}_{0}, \mathrm{I}_{1}\right.$ and $\left.\mathrm{I}_{2}\right)$ showed the poor LPn. The comparatively high LPn was observed under the treatments which included irrigation at the grain filling stage (80DAS) $\left(\mathrm{I}_{3}\right.$ and $\mathrm{I}_{4}$ ). Water deficit at post-anthesis might be one of the causes of the reduced LPn at the dough stage (90DAS) in $\mathrm{I}_{2}$. Liu and Chen (1990) 
Table 3. Effect of irrigation on leaf photosynthesis, leaf area index and crop growth rate of wheat.

\begin{tabular}{|c|c|c|c|c|c|}
\hline \multirow{2}{*}{ Treatment } & \multirow{2}{*}{ 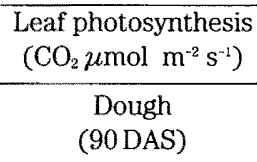 } & \multicolumn{2}{|c|}{ Leaf area index } & \multicolumn{2}{|c|}{$\begin{array}{l}\text { Crop growth rate } \\
\left(\mathrm{g} \mathrm{m}^{-2} \text { day }^{-2}\right)\end{array}$} \\
\hline & & $\begin{array}{c}\text { Dough } \\
\text { (90DAS) }\end{array}$ & $\begin{array}{c}\text { Maturity } \\
\text { (104 DAS) }\end{array}$ & $\begin{array}{c}\text { Dough } \\
\text { (90DAS) }\end{array}$ & $\begin{array}{l}\text { Maturity } \\
\text { (104DAS) }\end{array}$ \\
\hline $\mathrm{I}_{0}$ & $9.10 \mathrm{~b}$ & $2.32 \mathrm{c}$ & $0.38 \mathrm{~b}$ & $10.75 \mathrm{c}$ & $3.27 \mathrm{c}$ \\
\hline$I_{1}$ & $9.63 \mathrm{~b}$ & $2.70 \mathrm{~b}$ & $0.46 \mathrm{~b}$ & $13.00 \mathrm{bc}$ & $3.61 \mathrm{bc}$ \\
\hline$I_{2}$ & $9.50 \mathrm{~b}$ & $2.86 \mathrm{~b}$ & $0.51 \mathrm{~b}$ & $14.95 \mathrm{ab}$ & $4.60 \mathrm{~b}$ \\
\hline $\mathrm{I}_{3}$ & $13.52 \mathrm{a}$ & $3.51 \mathrm{a}$ & $0.76 \mathrm{a}$ & $15.50 \mathrm{a}$ & $5.63 \mathrm{ab}$ \\
\hline$I_{4}$ & $13.96 \mathrm{a}$ & $3.39 \mathrm{a}$ & $0.88 \mathrm{a}$ & $16.00 \mathrm{a}$ & $5.83 \mathrm{a}$ \\
\hline
\end{tabular}

Treatments having a common letter in column are not significantly different at $5 \%$ level.

Table 4. Effect of $\mathrm{N}$ application on leaf photosynthesis at different growth stages of wheat $\left(\mathrm{CO}_{2} \mu \mathrm{mol} \mathrm{m}^{-2} \mathrm{~s}^{-1}\right)$.

\begin{tabular}{cccc}
\hline Treatment & $\begin{array}{c}\text { Vegetative } \\
\text { (45DAS) }\end{array}$ & $\begin{array}{c}\text { Anthesis } \\
(70 D A S)\end{array}$ & $\begin{array}{c}\text { Dough } \\
(90 \mathrm{DAS})\end{array}$ \\
\hline $\mathrm{N}_{0}$ & $14.61 \mathrm{c}$ & $13.79 \mathrm{c}$ & $9.56 \mathrm{c}$ \\
$\mathrm{N}_{1}$ & $18.80 \mathrm{~b}$ & $20.97 \mathrm{~b}$ & $11.59 \mathrm{~b}$ \\
$\mathrm{~N}_{2}$ & $21.64 \mathrm{a}$ & $23.47 \mathrm{a}$ & $13.17 \mathrm{a}$ \\
$\mathrm{N}_{3}$ & $19.95 \mathrm{ab}$ & $21.92 \mathrm{ab}$ & $11.83 \mathrm{~b}$ \\
\hline
\end{tabular}

Treatments having a common letter in column are not significantly different at $5 \%$ level.

reported that LPn markedly decreased in wheat under intermediate and severe water deficit condition.

Leaf photosynthesis under different $\mathrm{N}$ treatments was monitored at the vegetative (45DAS), anthesis (70 DAS) and dough (90 DAS) stages (Table 4). Leaf photosynthesis was always highest at $120 \mathrm{~kg} \mathrm{~N}^{-1}\left(\mathrm{~N}_{2}\right)$ and lowest at $0 \mathrm{~kg} \mathrm{~N} \mathrm{ha}^{-1}\left(\mathrm{~N}_{0}\right)$ at each growth stage. Further increment in $\mathrm{N}$ dose to the highest level $\left(160 \mathrm{~kg} \mathrm{~N} \mathrm{ha}^{-1}\right)\left(\mathrm{N}_{3}\right)$ caused the reduction of $\mathrm{LPn}$. The level of $160 \mathrm{~kg} \mathrm{~N} \mathrm{ha}^{-1}$ might be in excess in the wheat cultivation on a clay terrace soil of Madhupur tract in Bangladesh. Increase in LPn due to increased N application was reported by Banziger et al. (1994). On the contrary, Champigny et al. (1991) reported the decreased LPn with increasing the $\mathrm{N}$ level under field condition. Leaf photosynthesis was higher at the anthesis stage irrespective of the treatments (Table 4). It might be due to the higher demand of photosynthates by reproductive organs. The results are in agreement with the findings of Frederick and Camberato (1994), who reported that the leaf net $\mathrm{CO}_{2}$ exchange rate (CER) of wheat increased at anthesis and decreased rapidly during the grain filling stage.

\section{Leaf area index}

The effect of irrigation on LAI was studied at the dough (90DAS) and maturity (104 DAS) stages (Table 3). At both stages significantly higher values of LAI were noted in $\mathrm{I}_{3}$ and $\mathrm{I}_{4}$ where irrigation at the grain filling stage (80 DAS) was included. There was no 


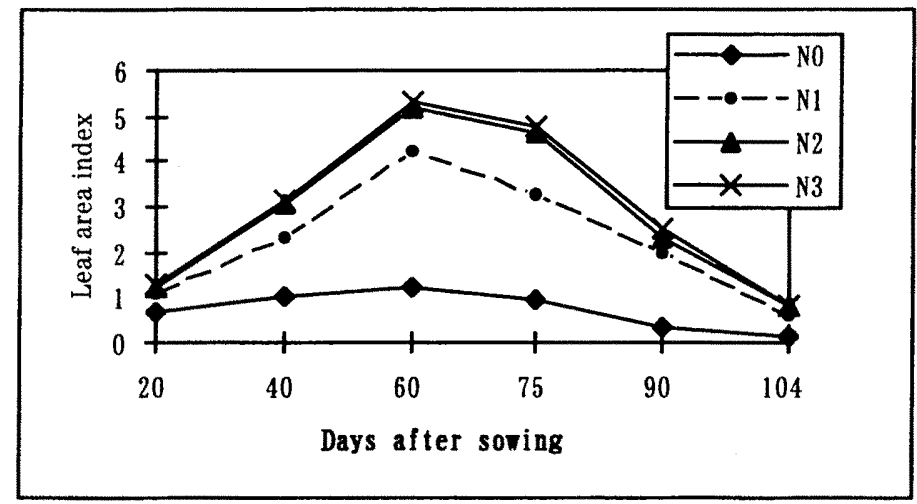

Fig. 1. Leaf area index of wheat at different days after sowing as influenced by the $\mathrm{N}$ treatment.

Table 5. Interaction effect of irrigation and $\mathrm{N}$ application on leaf area index at the dough stage (90DAS) of wheat.

\begin{tabular}{ccccccc}
\hline Treatment & \multicolumn{1}{c}{$\mathrm{I}_{0}$} & \multicolumn{1}{c}{$\mathrm{I}_{1}$} & \multicolumn{1}{c}{$\mathrm{I}_{2}$} & \multicolumn{1}{c}{$\mathrm{I}_{3}$} & \multicolumn{1}{c}{$\mathrm{I}_{4}$} & Mean \\
\hline $\mathrm{N}_{0}$ & $0.59 \mathrm{~B} \mathrm{a}$ & $0.90 \mathrm{C} \mathrm{a}$ & $0.98 \mathrm{C} \mathrm{a}$ & $1.00 \mathrm{C} \mathrm{a}$ & $1.00 \mathrm{C} \mathrm{a}$ & $0.89 \mathrm{C}$ \\
$\mathrm{N}_{1}$ & $2.77 \mathrm{~A} \mathrm{~b}$ & $2.58 \mathrm{~B} \mathrm{~b}$ & $2.69 \mathrm{~B} \mathrm{~b}$ & $3.67 \mathrm{~B} \mathrm{a}$ & $3.21 \mathrm{~B} \mathrm{ab}$ & $2.98 \mathrm{~B}$ \\
$\mathrm{~N}_{2}$ & $3.05 \mathrm{~A} \mathrm{C}$ & $3.59 \mathrm{~A} \mathrm{C}$ & $3.83 \mathrm{~A} \mathrm{bc}$ & $4.79 \mathrm{~A} \mathrm{a}$ & $4.56 \mathrm{~A} \mathrm{ab}$ & $3.96 \mathrm{~A}$ \\
$\mathrm{~N}_{3}$ & $2.85 \mathrm{~A} \mathrm{C}$ & $3.73 \mathrm{~A} \mathrm{~b}$ & $3.96 \mathrm{~A} \mathrm{~b}$ & $4.61 \mathrm{~A} \mathrm{ab}$ & $4.79 \mathrm{~A} \mathrm{a}$ & $3.99 \mathrm{~A}$ \\
Mean & $2.32 \mathrm{c}$ & $2.70 \mathrm{~b}$ & $2.86 \mathrm{~b}$ & $3.51 \mathrm{a}$ & $3.39 \mathrm{a}$ & 2.96 \\
\hline
\end{tabular}

Treatments having a common capital letter in column and those having a common small letter in row are not significantly different at $5 \%$ level.

significant variation in LAI between these two treatments. Rizzo et al. (1989) reported that LAI of wheat varied with irrigation levels and concluded that frequent irrigation had a significant effect on increasing LAI and green area duration, similar to our findings.

The effect of $\mathrm{N}$ application on LAI was distinct at all the growing days of wheat (Fig. 1). Nitrogen application at the rate of $160 \mathrm{~kg} \mathrm{ha}^{-1}\left(\mathrm{~N}_{3}\right)$ exhibited the highest LAI at all the growing days except for 104DAS (maturity stage). Leaf area index as recorded in $\mathrm{N}_{2}$ $\left(120 \mathrm{~kg} \mathrm{ha}^{-1}\right)$ was statistically similar to that of $\mathrm{N}_{3}\left(160 \mathrm{~kg} \mathrm{ha}^{-1}\right)$. In $\mathrm{N}_{3}$ and $\mathrm{N}_{2}$, LAI quickly increased from early growing days, attained the maximum at 60 DAS (booting stage) with LAI over 5, and then quickly decreased to the value of less than 1 at 104 DAS. A less quick change of LAI was observed in $N_{1}\left(80 \mathrm{~kg} \mathrm{ha}^{-1}\right)$ and the maximum value was about 4 at 60 DAS. In contrast, LAI in $\mathrm{N}_{0}$ hardly changed until $75 \mathrm{DAS}$ (anthesis stage), showing the value of around 1, and gradually decreased toward 104 DAS. The linear decrease in leaf area of wheat throughout flowering to maturation was reported by Wu et al. (1992).

The interaction effect of irrigation and $\mathrm{N}$ application on LAI at the dough stage (90 DAS) is presented in Table 5. Under respective irrigation levels LAI varied significantly with the variation of $\mathrm{N}$ application rates. Similarly, under respective $\mathrm{N}$ 
application rates LAI differed significantly with the variation of irrigation levels with a exception of $\mathrm{N}_{0}$ where irrigation treatment could not create any significant impact on LAI. As a result, the significantly highest values of LAI (4.6 to 4.8) were observed in combinations of $\mathrm{I}_{3}$ and $\mathrm{I}_{4}$ with $\mathrm{N}_{2}$ and $\mathrm{N}_{3}$. These results are in agreement with the findings of Parameswaran et al. (1984), who reported that adequate $\mathrm{N}$ and water supply gave rise to a higher LAI and post-anthesis green area duration in wheat.

\section{Crop growth rate}

The effect of irrigation on CGR at the dough (90 DAS) and maturity (104 DAS) stages was remarkable (Table 3). Significantly higher CGR was noted in the treatments which included irrigation at the grain filling stage $\left(\mathrm{I}_{3}\right.$ and $\left.\mathrm{I}_{4}\right)$. The result is similar to the findings of Amin (1997) who reported that irrigation at 50\% depletion of available soil moisture caused greater CGR than irrigation at the higher soil moisture depletion. The effect of $\mathrm{N}$ application on CGR was found to be distinct at all the growing days (Fig. 2). The performance of the higher $\mathrm{N}$ levels in $\mathrm{N}_{2}\left(120 \mathrm{~kg} \mathrm{ha}^{-1}\right)$ and $\mathrm{N}_{3}\left(160 \mathrm{~kg} \mathrm{ha}^{-1}\right)$ was better and statistically similar. In those $\mathrm{N}$ levels CGR rapidly increased after 40DAS (vegetative stage), attained the maximum at 75DAS (anthesis stage) with the value of around $25 \mathrm{~g}$ $\mathrm{m}^{-2}$ day $^{-1}$, and then showed the sharp reduction. In $\mathrm{N}_{1}\left(80 \mathrm{~kg} \mathrm{ha}^{-1}\right)$ a little lower CGR was observed in all the growing days with a similar pattern of the variation with DAS, but the increase in CGR at 60 to 75 DAS (booting to anthesis stages) was quite small in $\mathrm{N}_{0}$.

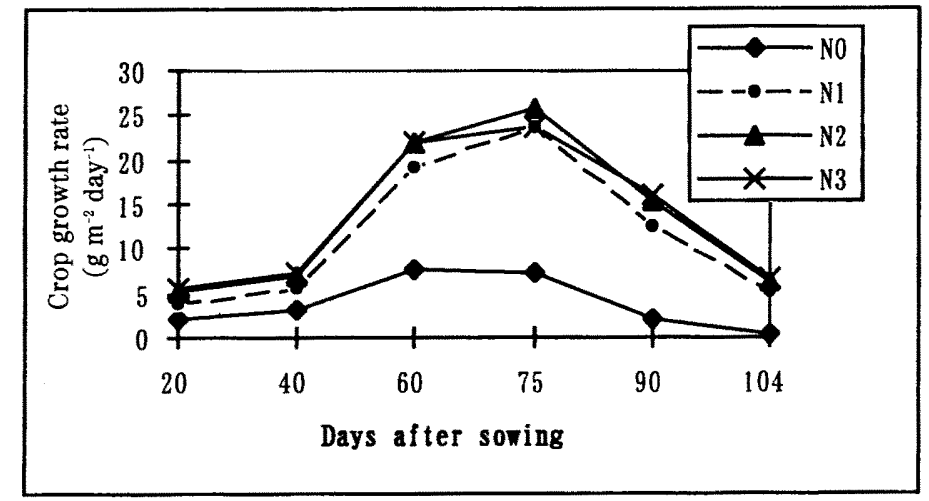

Fig. 2. Crop growth rate of wheat at different days after sowing as influenced by the $\mathrm{N}$ treatment.

\section{Dry matter production and partitioning}

Grain yield is a function of dry matter (DM) production and harvest index. Measurement of DM production and its partitioning are important for assessing the crop performance under a particular environment. The effect of irrigation on DM production of wheat was studied at the dough (90 DAS) and maturity (104 DAS) stages (Fig. 3). The plants receiving irrigation at the grain filling stage (80DAS) $\left(I_{3}\right.$ and $\left.I_{4}\right)$ performed better 
in this respect. Irrigation at the grain filling stage provided the higher weight of spike plus grain that contributed in increasing DM production at maturation. Variation in DM accumulation due to the difference in soil moisture content was also reported by Sharma and Chaudhary (1983).

The effect of $\mathrm{N}$ application on DM production of wheat was found to be distinct at all the growth stages (Fig. 4). The DM production increased with the increasing rate of $N$ application up to $160 \mathrm{~kg} \mathrm{ha}^{-1}\left(\mathrm{~N}_{3}\right)$. The maximum weight of leaf was recorded at the booting stage (60DAS) which decreased gradually at the later growth stages. Again, the maximum weight of culm was recorded at the dough stage (90DAS) which decreased gradually to the maturity stage. The reduction of leaf and culm weights at the post-reproductive stage might be due to translocation of assimilates from vegetative to

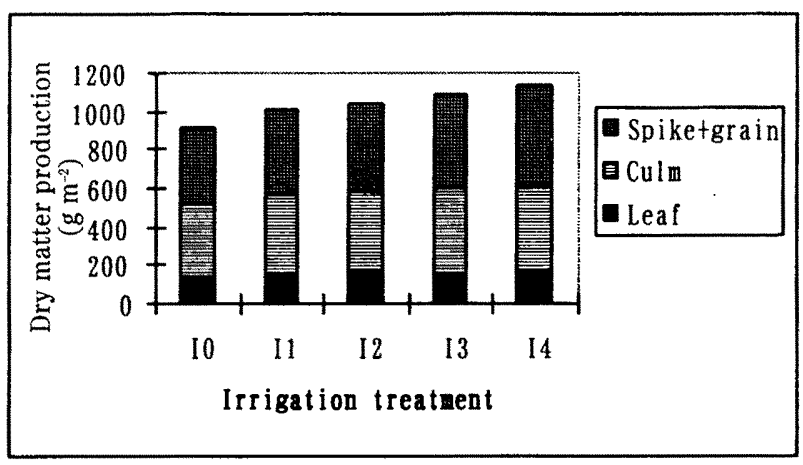

\section{(a) Dough stage (90 DAS)}

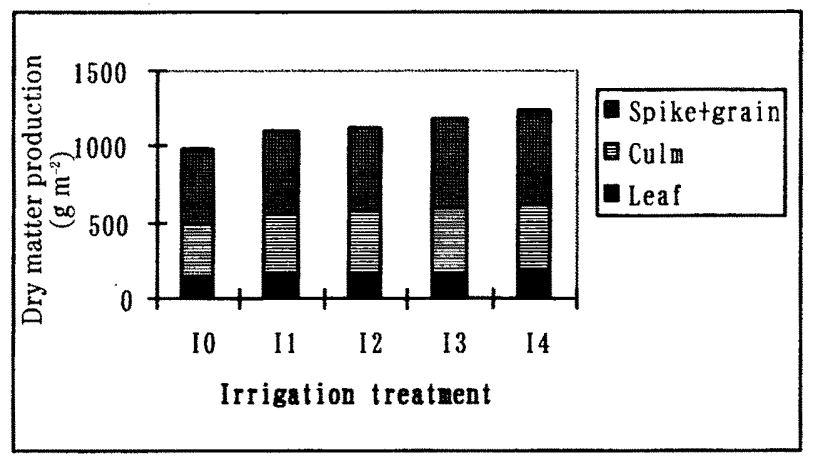

\section{(b) Maturity stage (104 DAS)}

Fig. 3. Effect of irrigation on dry matter production and partitioning of wheat at the dough and maturity stages. 


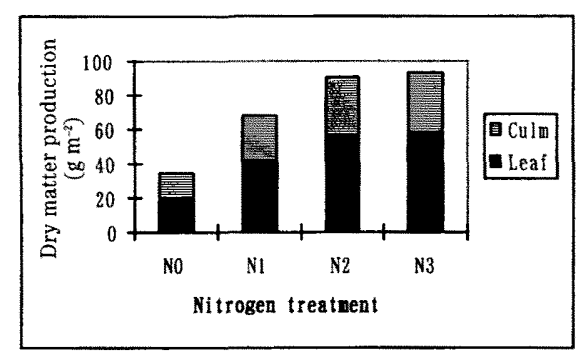

(a) Crown root initiation stage (20 DAS)

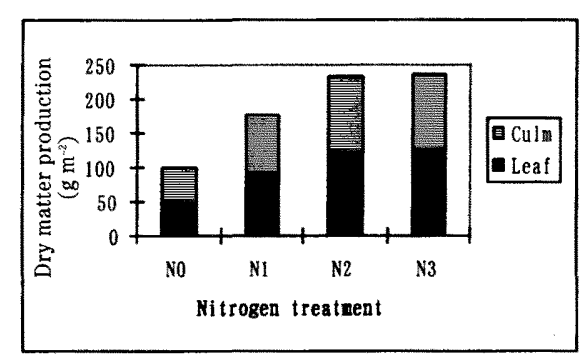

(b) Tillering stage (40 DAS)

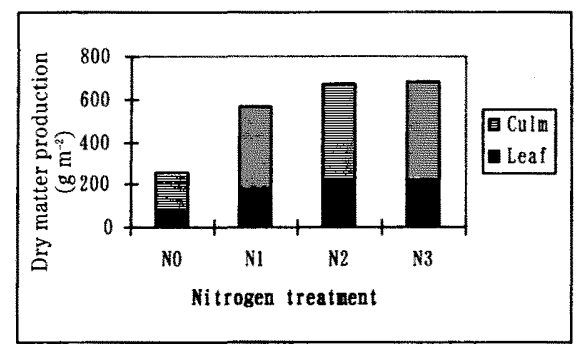

(c) Booting stage (60 DAS)

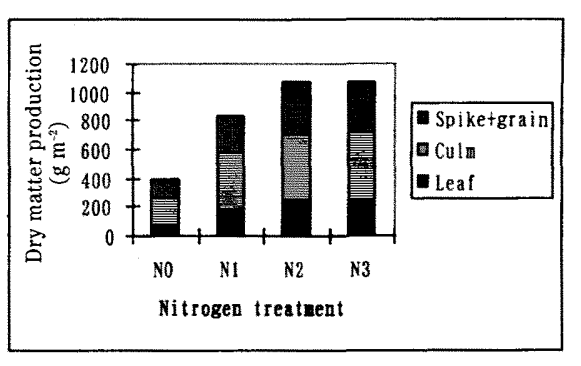

(d) Anthesis stage (75 DAS)

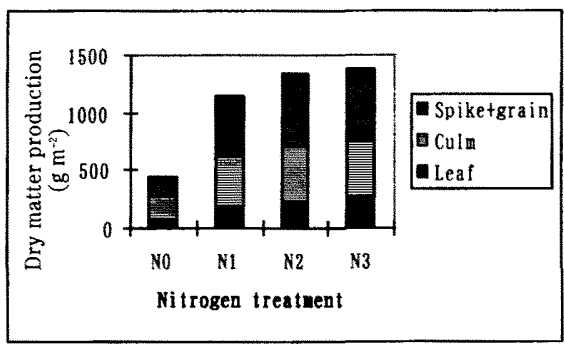

(e) Dough stage (90 DAS)

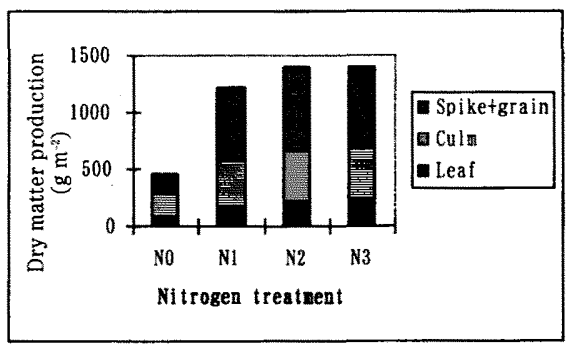

(f) Maturity stage (104 DAS)

Fig. 4. Effect of $\mathrm{N}$ application on dry matter production and partitioning of wheat at different growth stages. 
reproductive organs. The results are in agreement with the findings of Oscarson et al. (1995), who reported that production of vegetative DM decreased around 90DAS and that after 90 DAS increase in the total DM weight was solely attributed to the increased grain weight.

The weight of spike plus grain was influenced significantly by the $\mathrm{N}$ treatment, and at maturation it was highest for $\mathrm{N}_{2}\left(120 \mathrm{~kg} \mathrm{~N} \mathrm{ha}^{-1}\right)$ (Fig. 4). Although the weight of vegetative parts did not increase at the post-reproductive stage, the total DM production increased up to the maturity stage (104DAS) irrespective of $\mathrm{N}$ application rates. Grain development and the increased grain weight have led to such increment in total DM production. Johnston and Flowler (1991) reported that DM yield of wheat increased up to maturity under optimum soil moisture and $\mathrm{N}$ supply.

\section{Biomass production}

Final biomass production is the results of plant growth, DM accumulation and photosynthates produced by leaves and green plant-parts. Both irrigation and $\mathrm{N}$ application individually and combinedly created a significant effect on biomass production at harvest (Table 6). From the two-way comparison of mean, it was found that final biomass production was not significantly influenced by different irrigation levels under lower $\mathrm{N}$ application rates $\left(\mathrm{N}_{0}\right.$ and $\left.\mathrm{N}_{1}\right)$, but it increased in favour of irrigation under higher $\mathrm{N}$ application rates $\left(\mathrm{N}_{2}\right.$ and $\left.\mathrm{N}_{3}\right)$. In general, biomass production increased with the increasing $\mathrm{N}$ application rate up to $120 \mathrm{~kg} \mathrm{ha}^{-1}$, and the highest biomass $\left(16.29 \mathrm{Mg} \mathrm{ha}^{-1}\right)$ was obtained with $\mathrm{N}_{2}$ coupled with $\mathrm{I}_{4}$. The results are in agreement with the findings of Islam and Shamsuddin (1978), Panda et al. (1988) and Hooker et al. (1983).

Table 6. Interaction effect of irrigation and $\mathrm{N}$ application on biomass production of wheat at harvest $\left(\mathrm{Mg} \mathrm{ha}^{-1}\right)$.

\begin{tabular}{crcrrrr}
\hline Treatment & \multicolumn{1}{c}{$\mathrm{I}_{0}$} & \multicolumn{1}{c}{$\mathrm{I}_{1}$} & \multicolumn{1}{c}{$\mathrm{I}_{2}$} & \multicolumn{1}{c}{$\mathrm{I}_{3}$} & \multicolumn{1}{c}{$\mathrm{I}_{4}$} & Mean \\
\hline $\mathrm{N}_{0}$ & $3.63 \mathrm{~B} \mathrm{a}$ & $4.21 \mathrm{C} \mathrm{a}$ & $4.61 \mathrm{C} \mathrm{a}$ & $4.84 \mathrm{C} \mathrm{a}$ & $4.79 \mathrm{C} \mathrm{a}$ & $4.40 \mathrm{C}$ \\
$\mathrm{N}_{1}$ & $12.58 \mathrm{~A} \mathrm{a}$ & $12.02 \mathrm{~B} \mathrm{a}$ & $12.82 \mathrm{~A} \mathrm{a}$ & $12.84 \mathrm{~B} \mathrm{a}$ & $12.78 \mathrm{~B} \mathrm{a}$ & $12.61 \mathrm{~B}$ \\
$\mathrm{~N}_{2}$ & $12.60 \mathrm{~A} \mathrm{C}$ & $13.10 \mathrm{AB} \mathrm{bc}$ & $13.97 \mathrm{~A} \mathrm{~b}$ & $15.64 \mathrm{~A} \mathrm{a}$ & $16.29 \mathrm{~A} \mathrm{a}$ & $14.32 \mathrm{~A}$ \\
$\mathrm{~N}_{3}$ & $11.29 \mathrm{~A} \mathrm{~b}$ & $14.37 \mathrm{~A} \mathrm{a}$ & $14.03 \mathrm{~A} \mathrm{a}$ & $14.99 \mathrm{~A} \mathrm{a}$ & $15.36 \mathrm{~A} \mathrm{a}$ & $14.01 \mathrm{~A}$ \\
Mean & $10.00 \mathrm{~d}$ & $10.93 \mathrm{c}$ & $11.36 \mathrm{bc}$ & $12.08 \mathrm{ab}$ & $12.30 \mathrm{a}$ & 11.34 \\
\hline
\end{tabular}

Treatments having a common capital letter in column and those having a common small letter in row are not significantly different at $5 \%$ level.

\section{CONCLUSIONS}

From the present information it may be concluded that both irrigation and $\mathrm{N}$ application have a significant influence on LPn, LAI, CGR and biomass production of wheat. Irrigation scheduling which includes irrigation at the grain filling stage coupled with $\mathrm{N}$ application up to $120 \mathrm{~kg} \mathrm{ha}^{-1}$ produces the significantly highest LPn, LAI, CGR and biomass production. With respect to the growth stage, LPn and CGR are highest at the 
anthesis stage while LAI is maximum at the booting stage. Increased total DM accumulation at maturation is solely due to the increased weight of grains.

\section{REFERENCES}

Al-Khatib, K. and G. M. Paulsen 1990 Photosynthesis and productivity during high-temperature stress of wheat genotypes from major world regions. Crop Sci., 30: 1127-1132

Amin, M. 1997 Seed Bed Conditions, Sowing Depth, and Phosphorus Fertilizer Effect on Root. Growth, Nutrient Uptake, and Yield of Wheat. Ph.D. thesis in Agronomy, BSMRAU, Salna, Gazipur, Bangladesh

Banziger, M., B. Feil and P. Stamp 1994 Competition between nitrogen accumulation and grain growth for carbohydrates during grain filling of wheat. Crop Sci., 34: 440-446

Benbi, D. K. 1994 Prediction of leaf area indices and yields of wheat. J. Agric. Sci., 122: 13-20

Champigny, M. L., L. V. Quy, M. H. Valadier and A. Moyse 1991 Short term effects of nitrogen on $\mathrm{CO}_{2}$ photo assimilation and sucrose synthesis in wheat leaves. Physiol. Veg., 312: 469-476

Frederick, J. R. and J. J. Camberato 1994 Leaf net $\mathrm{CO}_{2}$ exchange rate and associated leaf traits of winter wheat grown with various nitrogen fertilizer rates. Crop Sci., 34: 432-439

Hooker, M. L., S. H. Mohiuddin and E. T. Kanemasu 1983 The effect of irrigation timing on yield and yield components of winter wheat. Canadian J. Plant Sci., 63: 815-823

Hsiao, T. C. 1973 Plant response to water stress. An. Rev. Plant Physiol., 24: 519-570

Islam, M. S. and A. M. Shamsuddin 1978 Effects of fertilizer under different levels of irrigation. Indian J. Agron., 23: 354361

Johnston, A. M. and D. B. Flowler 1991 No-till winter wheat dry matter and tissue nitrogen response to nitrogen fertilizer form and placement. Agron. J., 83: 722-728

Karim, A. J. M. S. and K. Egashira 1995 Agroclimatic conditions and soil water balance in the terrace soil area of Bangladesh. Bull. Inst. Trop. Agric., Kyushu Univ., 17: 45-58

Karim, Z., S. M. Rahman, M. Idris and A. J. M. S. Karim 1988 A Manual for the Determination of Soil Physical Parameters. Bangladesh Agricultural Research Council, Dhaka, Bangladesh

Liu, M. -Y. and P. - Y. Chen 1990 Effect of stomatal and non-stomatal factors on wheat photosynthesis under water stress. Plant Physiol. Communications, 4: 24-27

Oscarson, P., T. Lundborg, M. Larsson and C. -M. Larsson 1995 Genotypic differences in nitrate uptake and nitrogen utilization for spring wheat grown hydrophonically. Crop Sci, 35: 1056-1062

Panda, S. C., J. M. L. Gulati and B. Misra 1988 Effect of water regimes and nitrogen on wheat. Indian J. Agron., 33: 364-367

Parameswaran, K.V. M., R. D. Graham and D. Aspinall 1984 Studies on the nitrogen and water relations of wheat. II. Effects of varying nitrogen and water supply on growth and grain yield. Irrigation Sci., 5:105-121

Rizzo, V., V. D. Bari, M. Maiorana and G. Convertini 1989 The effect of irrigation regime on durum wheat (Triticum durum Desf.) grain yield and nitrogen uptake in Mediterranean thermal environment. Rivista-di-Agronomia, 23: 385-390

Sharma, B. R. and T. N. Chaudhary 1983 Wheat root growth, grain yield, and water uptake as influenced by soil water regime and depth of nitrogen placement in a loamy sand soil. Agric. Water Management, 6: $365-373$

Singh, V. K. and O. P. Dubey 1989 Response of wheat to different levels of irrigation and nitrogen. Current Research, University of Agric. Scie, Bangalore, 18: 169-170

Wu, J. -M., J. -Z. Wei, J. - H. Pan and L. -Y. Gong 1992 A study of wheat growth during grain filling stage. Jiangsu Agric. Sci, 2:1-4 